\title{
Effect of N Acethylcystein and Methylprednisolone on Acute Pancratitis and Lung Complications in Experimental Acute Pancratitis Model
}

\section{Deneysel Akut Pankreatit Modelinde N Asetilsistein Ile Metilprednisolon'un Akut Pankreatit ve Akciğer Komplikasyonları Üzerine Etkisi}

\author{
Hasan ELKAN ${ }^{1}(\mathbb{D})$, Hüsnü SÖNMEZ ${ }^{2}$, Figen DORAN ${ }^{3}$, Besim ÖZAYKAN ${ }^{4}$, \\ AtılganTolga AKÇAM ${ }^{2}(\mathbb{D})$, İsmail Cem ERAY ${ }^{2}$ (D) , Orçun YALAV ${ }^{2}$ (D)
}

\footnotetext{
1 Harran University Medical Faculty, Department of General Surgery, Sanliurfa, Turkey

${ }^{2}$ Çukurova University Medical Faculty, Department of General Surgery. Adana, Turkey

${ }^{3}$ Çukurova University Medical Faculty, Department of Pathology. Adana, Turkey

${ }^{4}$ Çukurova University Medical Faculty, Department of Physiology. Adana, Turkey
}

Background: This study aims to determine $\mathrm{N}$-acetyl cysteine (NAC) and methylprednisolone effects on the lung and pancreas in an experimental acute pancreatitis model.

Materials and Methods: A total of 64 male Wistar albino rats weighing $175-240 \mathrm{~g}$ were included in the study. Four groups of an equal number of rats $(n=16)$ were formed. For the control group, $80 \mathrm{mcg} / \mathrm{kg}$ saline was injected into group $1.80 \mathrm{mcg} / \mathrm{kg}$ cerulein was used to induce pancreatitis in groups 2, 3, and 4. Group 3 received NAC $(1,000 \mathrm{mg} / \mathrm{kg})$ and group 4 received methylprednisolone $(5 \mathrm{mg} / \mathrm{kg})$. Decapitation was applied to half of the groups after 7 hours (short term) and the other half after 24 hours (long term). Blood amylase and lipase values were examined. Edema in the pancreatic tissue was evaluated using the Schönberg scoring. Lung tissue was evaluated using scoring ranging from 0 to 3 .

Results: Pancreatitis was successfully induced in all subjects in groups 2, 3, and 4. Amylase and lipase values of group 3 and group 4 were lower than group 2 in the short term $(p<0.005)$. For short-term results, subjects given methylprednisolone and NAC exhibited better histopathological status in both pancreas and lungs ( $p=$ $0.001 ; p=0.019$, respectively). Only the pancreatic Schönberg score was significantly lower in the methylprednisolone treatment group $(p=0.0001)$.

Conclusions: Our study revealed that NAC and methylprednisolone have positive effects in the short term both biochemically and histopathologically in the treatment of acute pancreatitis and related respiratory complications.

Key Words: Acute pancreatit, $\mathrm{N}$-acetyl cysteine, Methylprednisolone

öz.

Amaç: Bu çalışma, deneysel akut pankreatitte $\mathrm{N}$-asetil sisteinin (NAC) ve metilprednizolonun, akciğer ve pankreas üzerindeki etkilerini belirlemeyi amaçlamaktadır.

Materyal ve Metod: Çalışmaya $175-240 \mathrm{gr}$ ağırlı̆̆ında toplam 64 adet erkek Wistar albino sıçan dahil edildi. Eşit sayıda sıçan ( $\mathrm{n}=16)$ olan dört grup oluşturuldu. Kontrol grubu için grup 1'e $80 \mathrm{mcg} / \mathrm{kg}$ salin enjekte edildi. Grup 2,3 ve 4'te pankreatiti indüklemek için $80 \mathrm{mcg} / \mathrm{kg}$ serulein kullanıldı. Grup 3'e NAC $(1,000 \mathrm{mg} / \mathrm{kg})$ ve Grup 4'e metilprednizolon $(5 \mathrm{mg} / \mathrm{kg}$ ) verildi. Grupların yarısına 7 saat sonra (kısa dönem), diğer yarısına 24 saat sonra (uzun dönem) dekapitasyon uygulandı. Kan amilaz ve lipaz değerleri incelendi. Pankreas dokusundaki ödem, Schönberg skorlaması kullanılarak değerlendirildi. Akciğer dokusu, 0 ila 3 arasında değişen puanlama kullanılarak değerlendirildi.

Bulgular: Grup 2, 3 ve 4'te tüm deneklerde pankreatit başarıyla indüklendi. Grup 3 ve grup 4'ün amilaz ve lipaz değerleri grup 2'ye göre kısa dönemde daha düşüktü $(p<0,005)$. Kısa dönem sonuçlar için, metilprednizolon ve NAC verilen denekler hem pankreasta hem de akciğerlerde daha iyi histopatolojik durum sergiledi (sırasıyla $p=0.001 ; p=0.019$ ). Uzun dönem sonuçlar için, metilprednizolon tedavi grupunda sadece pankreas Schönberg skoru anlamlı olarak daha düşüktü $(p=0.0001)$.

Sonuç: Çalışmamız, akut pankreatit ve buna bağlı solunumsal komplikasyonların tedavisinde NAC ve metilprednizolon hem biyokimyasal hem de histopatolojik olarak kısa vadede olumlu etkileri olduğu ortaya koymuştur.

Anahtar kelimeler: Akut pankreatit, $\mathrm{N}$-asetil sistein, Metilprednizolon
Corresponding Author / Sorumlu Yazar

\section{Dr. Hasan Elkan}

Harran University Medical Faculty

Department of General Surgery,

Sanliurfa, Turkey

E-mail:dr_elkan@hotmail.com

Received / Geliş tarihi: 22.08.2021

Accepted / Kabul tarihi: 19.10.2021

DOI: $10.35440 /$ hutfd. 985720

Bu çalışma Dr. Hasan ELKAN'ın tıpta uzmanlık tezinden türetilmiştir. 


\section{Introduction}

Acute pancreatitis is an acute inflammation that develops with the leakage and activation of pancreatic enzymes into the pancreatic parenchyma, resulting in gland auto-digestion.

There have been sharp increases in acute pancreatitis incidence over the last 30 years worldwide (1). Overall mortality was reported approximately 5 percent, with mortality rates in patients with interstitial, necrotizing pancreatitis, 3 percent, and 17 percent, respectively (2). About one-third of patients with acute pancreatitis have pulmonary complications. Complications of the pulmonary system have been attributed to severe damage to the lung parenchyma caused by cytokines secreted during pancreatic inflammation (3). These cytokines increase the capillary permeability, leukocyte adherence, and extravasation, leading to the aggravation of acute pancreatitis and systemic complications. Reactive oxygen radicals are also an important factor in the formation and progression of acute pancreatitis and pulmonary complications (4). The antioxidant properties of $\mathrm{N}$-acetyl cysteine and the anti-inflammatory effects of glucocorticoids are thought to be effective in treating acute pancreatitis $(5,6)$. Corticosteroids, affect different cell types involved in inflammatory processes, inhibit the proliferation and function of macrophages and fibroblasts. Similarly, it shows anti-inflammatory activity by inhibiting both the production and release of cytokines such as IL-1, IL-6, TNF (tumor necrosis factor) alpha (7). They also affect the production of arachidonic acid metabolites and suppress the proinflammatory response in endothelial cells (8).

This study aimed to demonstrate the biochemical and histopathological effects of $\mathrm{N}$-acetyl cysteine and methylprednisolone in experimental acute pancreatitis models.

\section{Materials and Methods}

A total of 64 male Wistar albino rats weighing between 175$240 \mathrm{~g}$ were included in the study. Four groups with an equal number of rats $(n=16)$ were formed.

Group 1: For the control group, a total of $80 \mathrm{mcg} / \mathrm{kg}$ of saline was injected subcutaneously into 16 rats six times at 1-hour intervals.

Group 2: For the pancreatitis group, cerulein was injected subcutaneously six times (total dose $80 \mathrm{ug} / \mathrm{kg}$ ) to 16 rats at 1hour intervals.

Group 3: Cerulein was injected subcutaneously six times (total dose $80 \mathrm{mcg} / \mathrm{kg}$ ) to 16 rats at 1-hour intervals, and 1,000 $\mathrm{mg} / \mathrm{kg}$ of $\mathrm{N}$-acetylcysteine was injected intraperitoneally every one hour.

Group 4: Cerulein was injected subcutaneously six times (total dose $80 \mathrm{mcg} / \mathrm{kg}$ ) to 16 rats at 1-hour intervals, and $5 \mathrm{mil}-$ ligrams/kg of methylprednisolone was injected twice at 1hour intervals.

The groups were divided into two groups in equal numbers $(n=8)$. Decapitation was applied to the first groups 7 hours after the first cerulein injection (short term).
In the other groups, decapitation wasperformed 24 hours after the first cerulein injection (long term).

Biochemical Evaluation: Approximately 4-5 cc of blood was taken from the neck vessels after decapitation from each rat, and the serum was separated by centrifugation at 3,500 Rpm at $+4^{\circ} \mathrm{C}$ for 10 minutes. $0.5 \mathrm{cc}$ of serum was put into Eppendorf tubes for amylase and lipase. Amylase and lipase levels were measured with the Roche Preanalytil modular System (DPP) device according to the International Federation of Clinical Chemistry (IFCC). The amylase and lipase values at the 7 th hour were considered short-term results, while the results at the 24th hour were deemed to be long-term effects. Histopathological Evaluation: Following decapitation, rats' pancreatic tissue and right lung lobe were removed for histopathological evaluation. For pancreatitis, histopathological findings of the groups were evaluated according to the Schönberg score (9) in terms of fat necrosis, interstitial edema, vocalization, and polymorphonuclear cell infiltration (Table 1, Figure 1). Lung damage, as defined by Balkan et al. (10) were evaluated considering hemorrhage in the lung tissue, edema, peribronchitis, and inflammation (Table 2, Figure 2).

Table 1. The scale used for histopathological evaluation of pancreatic tissue (Schönbergscoring)

\begin{tabular}{|l|l|l|l|l|}
\hline Score & Edema & $\begin{array}{l}\text { Vasculari- } \\
\text { zation }\end{array}$ & $\begin{array}{l}\text { Inflamma- } \\
\text { tion }\end{array}$ & Necrosis \\
\hline 0 & No & No & No & No \\
\hline 1 & $\begin{array}{l}\text { Diffuseenlarge- } \\
\text { ment of interlo- } \\
\text { bularsepta }\end{array}$ & $\begin{array}{l}\text { Periductal } \\
(<\% 5)\end{array}$ & Periductal & $\begin{array}{l}1-4 \text { Necro- } \\
\text { ticcell }\end{array}$ \\
\hline 2 & $\begin{array}{l}1 \quad(+) \text { Diffuseen- } \\
\text { largement of in- } \\
\text { terlobularsepta }\end{array}$ & $\begin{array}{l}\text { Focal } \\
(\% 5-20)\end{array}$ & $\begin{array}{l}\text { Intrapa- } \\
\text { renchymal } \\
(<\% 50 \text { inter- } \\
\text { lobular) }\end{array}$ & $\begin{array}{l}5-10 \text { Nec- } \\
\text { roticcell }\end{array}$ \\
\hline 3 & $\begin{array}{l}2 \quad(+) \text { Diffuseen- } \\
\text { largement of in- } \\
\text { terlobularsepta }\end{array}$ & $\begin{array}{l}\text { Diffuse } \\
(\% 21-50)\end{array}$ & $\begin{array}{l}\text { Intrapa- } \\
\text { renchymal } \\
(\% 51-75 \text { In- } \\
\text { terlobular) }\end{array}$ & $\begin{array}{l}11-16 \mathrm{Nec}- \\
\text { roticcell }\end{array}$ \\
\hline 4 & $\begin{array}{l}3 \quad(+) \text { Diffuseen- } \\
\text { largement of in- } \\
\text { terlobularsepta }\end{array}$ & $\begin{array}{l}\text { High } \\
(>\% 50)\end{array}$ & $\begin{array}{l}\text { Intrapa- } \\
\text { renchymal } \\
(>\% 75 \text { Inter- } \\
\text { lobular) }\end{array}$ & $\begin{array}{l}>16 \quad \text { Nec- } \\
\text { roticcell }\end{array}$ \\
\hline
\end{tabular}

Table 2. The scale used for histopathological evaluation of lung tissue

\begin{tabular}{|l|c|c|c|c|}
\hline Score & Edema & $\begin{array}{c}\text { Haemorr- } \\
\text { hage }\end{array}$ & $\begin{array}{c}\text { Inflamma- } \\
\text { tion }\end{array}$ & Peribronchitis \\
\hline 0 & No & No & No & No \\
\hline 1 & Weak & Weak & Weak & Weak \\
\hline 2 & Middle & Middle & Middle & Middle \\
\hline 3 & High & High & High & High \\
\hline
\end{tabular}




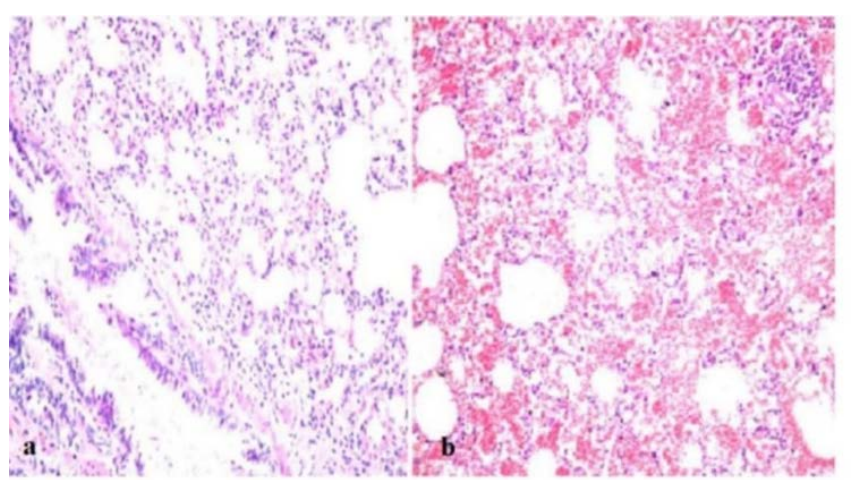

Figure 1. Histopathological examination of the pancreas (Staining with Hematoxylin and Eosin)

a) Normal pancreatic tissue

b) Histopathological view of acute pancreatitis (Polymorphonuclear leukocyte infiltration, edema, and necrose)
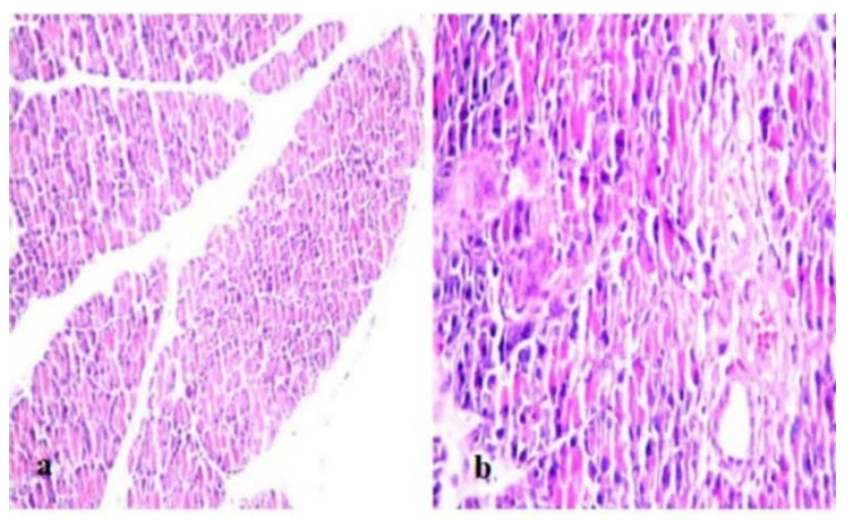

Figure 2. Histopathological examination of the lung (Staining with Hematoxylin and Eosin)

a) Normal lung tissue

b) Hemorrhage, edema, and peribronchial mononuclear cell infiltration in the lung

Statistical Evaluation: The Shapiro-Wilk normality test was used to verify data normality. Thedata's compliance to normal distribution was tested: t-test and one-way analysis of variance were used in independent groups in the analysis of continuous variables with normal distribution, whereas Mann Whitney $U$ or Kruskal Wallis tests were used in the analysis of continuous variables that did not show normal distribution. Data were expressed as mean \pm standard deviation, median (min-max). The value of $p<0.05$ was considered statistically significant. Bonferroni correction was made in multiple comparisons, and $p<0.017$ was deemed significant (p0.10/n; n= number of comparisons).

\section{Results}

In our study, pancreatitis was induced in all of 48 cases (Groups 2, 3, and 4) who received a subcutaneous injection of cerulein (total $80 \mathrm{mcg} / \mathrm{kg}$ ) (100\% success).

\section{Results of Amylase and Lipase Values}

The mean amylase and lipase values are given in table 3 . The evaluation of the short-term results revealed that the amylase and lipase values of the groups with pancreatitis (Group 2,3 , and 4) were statistically higher than the control group
(Group 1, Table 3). In the long-term results, no statistically significant difference was found between the groups ( $p=0.061, p=0.361$, respectively).

Table 3. Comparison of the results of amylase and lipase values of the groups

\begin{tabular}{|l|c|c|c|c|}
\hline \multirow{2}{*}{ Groups } & \multicolumn{2}{|c|}{$\begin{array}{c}\text { Shortterm (Mean } \pm \text { sd) } \\
\text { (IU/mL) }\end{array}$} & \multicolumn{2}{c|}{$\begin{array}{c}\text { Longterm (Mean } \pm \text { sd) } \\
\text { (IU/mL) }\end{array}$} \\
\cline { 2 - 5 } & Amylase & Lipase & Amylase & Lipase \\
\hline Group 1 & $2817 \pm 595$ & $237 \pm 137$ & $2648 \pm 463$ & $345 \pm 170$ \\
\hline Group 2 & $46782 \pm 9354$ & $4163 \pm 1366$ & $3442 \pm 890$ & $518 \pm 192$ \\
\hline Group 3 & $25799 \pm 2278$ & $2560 \pm 2282$ & $4203 \pm 1641$ & $428 \pm 152$ \\
\hline Group 4 & $38531 \pm 13277$ & $3181 \pm 1578$ & $3254 \pm 669$ & $413 \pm 327$ \\
\hline p & 0.0001 & 0.0001 & 0.061 & 0.361 \\
\hline
\end{tabular}

\section{Comparison of treatment groups in terms of amylase and} lipase

Long- and short-term serum amylase and lipase values of the treatment groups (Groups 3 and 4) were compared with the pancreatitis group's values (Group 2). Both Group 3 and 4 exhibited statistically significantly lower levels in the short term compared to Group 2. Nonetheless, no statistically significant difference was found in the long-term results (Table 4).

Table 4. Comparison of biochemical parameters of thetreatment groups with the pancreatitis group

\begin{tabular}{|c|c|c|c|c|}
\hline & & $\begin{array}{c}\text { Group } 2 \\
\text { (Mean } \pm s d) \\
(I U / m L)\end{array}$ & $\begin{array}{c}\text { Group } 3 \\
\text { (Mean } \pm s d) \\
(I U / m L)\end{array}$ & p \\
\hline \multirow{2}{*}{$\begin{array}{l}\text { Short- } \\
\text { term }\end{array}$} & Amylase & $46782 \pm 9354$ & $25799 \pm 2278$ & 0.0001 \\
\hline & Lipase & $4163 \pm 1366$ & $2560 \pm 2282$ & 0.0001 \\
\hline \multirow{2}{*}{$\begin{array}{l}\text { Long- } \\
\text { term }\end{array}$} & Amylase & $3442 \pm 890$ & $4203 \pm 1641$ & 0.574 \\
\hline & Lipase & $518 \pm 192$ & $428 \pm 152$ & 0.130 \\
\hline & & $\begin{array}{c}\text { Group } 2 \\
\text { (Mean } \pm s d) \\
(I U / m L)\end{array}$ & $\begin{array}{c}\text { Group } 4 \\
\text { (Mean } \pm s d) \\
(I U / m L)\end{array}$ & $\mathbf{P}$ \\
\hline \multirow{2}{*}{$\begin{array}{l}\text { Short- } \\
\text { term }\end{array}$} & Amylase & $46782 \pm 9354$ & $38531 \pm 13277$ & 0.0001 \\
\hline & Lipase & $4163 \pm 1366$ & $3181 \pm 1578$ & 0.0001 \\
\hline \multirow{2}{*}{$\begin{array}{l}\text { Long- } \\
\text { term }\end{array}$} & Amylase & $3442 \pm 890$ & $3254 \pm 669$ & 0.505 \\
\hline & Lipase & $518 \pm 192$ & $413 \pm 327$ & 0.721 \\
\hline
\end{tabular}

\section{Histopathologic Findings}

Short-term scores of Group 1 in terms of both pancreatic and lung damage were statistically significantly lower than the other groups ( $p=0.001 ; 0.019$, respectively). Only the pancreatic damage score was statistically significantly lower in the long-term results than the other groups $(p=0.001)$ (Table 5). The treatment groups (Group 3 and 4) and the pancreatitis group (Group 2) were compared in histopathological changes in Table 6. The treatment groups' scores in terms of both lung and pancreas were significantly lower than Group 2 in the short term. In the long-term results, only the pancreas score of group 4 was significantly lower than group 2, while the 
lung score was not statistically significant.

Table 5. Comparison of pancreas and lung scores according to histopathological examination

\begin{tabular}{|l|c|c|c|c|}
\hline Groups & \multicolumn{2}{|c|}{ Shortterm } & \multicolumn{2}{c|}{ Longterm } \\
\hline & $\begin{array}{c}\text { Pancreas } \\
\text { Score }\end{array}$ & Lung Score & $\begin{array}{c}\text { Pancreas } \\
\text { Score }\end{array}$ & $\begin{array}{c}\text { Lung } \\
\text { Score }\end{array}$ \\
\hline Group 1 & $0.75 \pm 0.046$ & $3.50 \pm 1.77$ & $1.1250 \pm 0.64$ & $4.25 \pm 1.48$ \\
\hline Group 2 & $8.12 \pm 0.83$ & $6.25 \pm 1.66$ & $6.87 \pm 1.45$ & $5.75 \pm 1.98$ \\
\hline Group 3 & $5.25 \pm 1.58$ & $4.87 \pm 1.35$ & $5.37 \pm 2.72$ & $6.12 \pm 1.45$ \\
\hline Group 4 & $3.87 \pm 0.99103$ & $4.25 \pm 1.03$ & $3.12 \pm 0.99$ & $5.0 \pm 1.41$ \\
\hline p & $\mathbf{0 . 0 0 1}$ & $\mathbf{0 . 0 1 9}$ & $\mathbf{0 . 0 0 1}$ & 0.161 \\
\hline
\end{tabular}

Table 6. Histopathological comparison of treatment groups and pancreatitis group

\begin{tabular}{|c|c|c|c|c|}
\hline & & $\begin{array}{c}\text { Grup } 2 \\
\text { (Mean } \pm \text { sd) }\end{array}$ & $\begin{array}{c}\text { Grup } 3 \\
\text { (Mean } \pm \text { sd) }\end{array}$ & $\mathbf{p}$ \\
\hline \multirow{2}{*}{$\begin{array}{l}\text { Short- } \\
\text { term }\end{array}$} & Pancreas Score & $8.12 \pm 0.83$ & $5.25 \pm 1.58$ & 0.002 \\
\hline & Lung Score & $6.25 \pm 1.66$ & $4.87 \pm 1.35$ & 0.030 \\
\hline \multirow[t]{2}{*}{ Longterm } & Pancreas Score & $6.87 \pm 1.45$ & $5.37 \pm 2.72$ & 0.279 \\
\hline & Lung Score & $5.75 \pm 1.98$ & $6.12 \pm 1.45$ & 0.721 \\
\hline & & $\begin{array}{c}\text { Grup } 2 \\
\text { (Mean } \pm \text { sd) }\end{array}$ & $\begin{array}{c}\text { Grup } 4 \\
\text { (Mean } \pm s d)\end{array}$ & $\mathbf{p}$ \\
\hline \multirow{2}{*}{$\begin{array}{l}\text { Short- } \\
\text { term }\end{array}$} & Pancreas Score & $8.12 \pm 0.83$ & $3.87 \pm 0.99103$ & 0.0001 \\
\hline & Lung Score & $6.25 \pm 1.66$ & $4.25 \pm 1.03$ & 0.015 \\
\hline \multirow[t]{2}{*}{ Longterm } & Pancreas Score & $6.87 \pm 1.45$ & $3.12 \pm 0.99$ & 0.0001 \\
\hline & Lung Score & $5.75 \pm 1.98$ & $5.0 \pm 1.41$ & 0.574 \\
\hline
\end{tabular}

\section{Discussion}

Acute pancreatitis is an autodigestion that begins with the transition of pancreatic enzymes to an active form in the gland (11). Serum amylase and lipase have been used as markers for pancreatitis in many studies; however, amylase alone bears weak significance (12). Serum lipase also increases in acute pancreatitis, perforated or penetrating peptic ulcer, or pancreatic duct obstruction, but may remain high for 14 days after it returns to normal, compared to serum amylase (12). Although known that amylase and lipase are not biochemically specific for pancreatitis, we examined these values to support our study's histopathological results.

Free oxygen radicals and cytokines generated in acute pancreatitis can join the systemic circulation and cause damage to many organs. One of the critical damages outside of the pancreas occurs in the lung tissue. In an experimental acute pancreatitis model, Guice et al. showed that edema formation and interalveolar bleeding developed due to endothelial cell damage and increased microvascular permeability in the lung tissue (13). The authors attributed this mechanism to complement activation and complement adhesion caused by superoxide dismutase and catalase enzymes. Neutrophils activated by these complement activations secrete oxygen radicals and cause lung damage by damaging the endothelium to which it adheres.

In the study of O'Donovan et al., they detected endothelial cell damage and edema formation in both pancreatic and lung tissue in the acute pancreatitis model induced with cerulein, and both events were thought to be related to neut- rophils (14).Also, they found that the lung damage that occurred was due to pulmonary edema, microvascular protein leakage, and neutrophil infiltration (14).

In a study by Choi et al., the effect of antioxidants was investigated in an experimental acute pancreatitis model induced by intravenous cerulein infusion in rats. The authors argued that N-Acetyl Cysteine (NAC), which they used to eliminate this effect, effectively correcting hyperamylasemia and tissue damage in acute pancreatitis (15). N-acetyl cysteine is thought to exert this anti-oxidant effect by reducing the formation of free oxygen radicals and increasing glutathione synthetase activity (5). In an experimental study in which Demols et al. examined the effects of $\mathrm{N}$-acetyl-cysteine on acute pancreatitis, they administered $1,000 \mathrm{mg} / \mathrm{kg}$ of NAC intraperitoneally one hour before (prophylactic group) and one hour after (therapeutic group) cerulein was administered intraperitoneally. In conclusion, the severity of acute pancreatitis decreased statistically in the prophylactic group compared to other groups (14).

Our study found that NAC significantly reduced the subjects' biochemical parameters, decapitated at the 7th hour. Nevertheless, this decrease was not statistically significant in subjects who were decapitated after 24 hours. We think that this is the spontaneous decrease in amylase and lipase levels in the long term, rather than the therapeutic effect of NAC. In our study, we used the Schönberg index to examine NAC's effect on the pancreatic tissue. The results of the subjects who underwent decapitation at the 7th hour revealed that NAC significantly reduced the Schönberg score in pancreatitis. On the other hand, we found that NAC reduced the Schönberg score in subjects who underwent decapitation at the 24th hour, but it was not statistically significant. We think that this is due to the short duration of the pharmacological action of NAC.

Balkan et al. examined the effect of NAC on the lung in rats with experimental pancreatitis. They found that pulmonary edema, hemorrhage, and neutrophil infiltration were statistically less common in the NAC group (10).Our study found that NAC exerted positive histopathological effects on the lung score in the short term.

Various mediators have been implicated in the pathogenesis of acute pancreatitis. Some of these mediators are proinflammatory cytokines such as TNFó, IL-1b, IL-6, IL-8, and the ratelimiting enzyme of arachidonic acid metabolism, phospholipase A2. Corticosteroids exhibit anti-inflammatory effects by blocking arachidonic acid formation in membrane phospholipids by inhibiting the phospholipase enzyme and prostaglandin synthesis (17). However, the application of glucocorticoids in the treatment of acute pancreatitis is still controversial (6). While some authors mentioned its positive effects on survival, some authors stated that it was associated with increased mortality, especially with high doses (18-20).

Nevertheless, recent publications have highlighted the positive effects of low-dose steroids on survival, especially in autoimmune pancreatitis (21-22). Takaoka et al. examined the 
effect of high-dose methylprednisolone following pancreatitis in rats. They found a decrease in the pancreas' dry weight, a reduction in IL-1ß and IL-6 levels, and a significant histological reduction in edema and necrosis in rats receiving methylprednisolone (23). Osman et al. found a statistically significant decrease in amylase, TNFó, and IL-8 levels in subjects receiving steroids (19).Our study found that the Schönberg scores of the subjects receiving methyl-prednisolone were lower both in the short and long term. Our result showed that methylprednisolone mightpositively affect inflammation, edema, necrosis, and vacuolization of pancreatitis.

\section{Conclusion}

The use of NAC and methylprednisolone in the treatment of acute pancreatitis has positive histochemical or biochemical effects on the pancreas and lungs in the short term.

Ethical Approval: This study was approved by the local animal experiments ethical committee of Cukurova University (Date: 29.09.2014, meeting no: 6 and decision no: 3)

\author{
Author Contributions: \\ Concept: H.E., O.Y. \\ Literature Review: H.E. \\ Design : B.Ö., i.C.E. \\ Data acquisition: H.E., F.D. \\ Analysis and interpretation: H.E., A.T.A. \\ Writing manuscript: H.E. \\ Critical revision of manuscript: H.E., H.S., ,i.C.E.
}

Conflict of Interest: The authors have no conflicts of interest to declare.

Financial Disclosure: Cukurova university scientific research projects (Ç.Ü.B.AP)

\section{References}

1. Roberts SE, Akbari A, Thorne K, Atkinson M, Evans PA. The incidence of acute pancreatitis: impact of social deprivation, alcohol consumption, seasonal and demographic factors. Aliment Pharmacol Ther 2013; 38: 539-48.

2. Banks PA, Freeman ML. Practice Parameters Committee of the American College of Gastroenterology. Practice guidelines in acute pancreatitis. Am J Gastroenterol 2006; 101: 2379-400.

3. Ranson JH, Turner JW, Roses DF, Rifkind KM, Spencer FC. Respiratory complications in acute pancreatitis. Ann Surg 1974; 179: 557-66.

4. Kruse $P$, Anderson ME, Loft $\mathrm{S}$. Minor role of oxidative stress durıng intermediate phase of acute pancreatitis in rats. Free Radical Biology \& Medicine 2001; 30: 309-17.

5. Sala R, Moriggi E, Corvasce G, Morelli D. Protection by Nacetylcysteine against pulmonary endothelial cell damage by oxidant injury. Eur Respir J 1993; 6: 440-6.

6. Pezzilli R, Fantin L. Glucocorticoids and Acute Pancreatitis: Suggestions for Future Clinical Trials. JOP. J Pancreas (Online)2006; 7: 249-51.

7. Awasthi $S$, Wagner $T$, Venkatakrishnan AJ, Puranik A, Hurchik $\mathrm{M}$, Agarwal V, et al. Plasma IL-6 levels following corticosteroid therapy as an indicator of ICU length of stay in critically ill COVID-19 patients. Cell death discovery. 2021;7(1):55.
8. Zielińska KA, Van Moortel L, Opdenakker G, De Bosscher K, Van den Steen PE. Endothelial Response to Glucocorticoids in Inflammatory Diseases. Frontiers in immunology. 2016;7:592. PubMed PMID: 28018358. Pubmed Central PMCID: PMC5155119. Epub 2016/12/27. Eng.

9. Schoenberg $M H$, Büchler $M$, Gaspar $M$, Stinner A. Oxygen free radicals in acute pancreatits of the rat. Gut 1990; 31: 1138-43.

10. Balkan A, Balkan M, Yasar M, Korkmaz A, Erdem O, Kılıc S, et al. Pulmonary Protective Effects of Hyberbaric Oxygen and $\mathrm{N}$-Acetylcysteine Treatment in Necrotizing Pancreatitis. Physiol Res 2006: 55; 25-31.

11. Karne S, Gorelik FS. Etiopathogenesis of acute pancreatitis. Surgical Clinics Of North America 1999; 79: 44: 699-709.

12. Boxhoorn L, Voermans RP, Bouwense SA, Bruno MJ, Verdonk RC, Boermeester MA, et al. Acute pancreatitis. Lancet 2020; 396: 726-34.

13. Guice KS, Oldham KT, Caty MG, Johnson KJ, Ward PA. Neutrophil-dependent, oxygen-radical mediated lung injury associated with acute pancreatitis. Ann Surg. 1989; 210: 740-7.

14. O'Donovan DA, Kelly CJ, Abdih H, Bouchier-Hayes D, Watson $\mathrm{RW}$, Redmond HP, et al. Role of nitric oxide in lung injury associated with experimental acute pancreatitis. $\mathrm{Br} J$ Surg 1995; 82: 1122-6.

15. Choi JY, Kim KH. Effects of small molecular antioxidants on cerulein-induced acute pancreatitis in rat. Korean J Physiopharmacol 1998; 2: 629-35.

16. Demols A, Van Laethem JL, Quertinmont E, Legros F, Louis H, Le Moine $\mathrm{O}$, et al. $\mathrm{N}$-acetylcysteine decreases severity of acute pancreatitis in mice. Pancreas. 2000; 20: 161-9.

17. Gloor B, Uhl W, Tcholakov O, Roggo A, Muller CA, Worni M, et al. Hydrocortisone treatment of early SIRS in acute experimental pancreatitis. Dig Dis Sci 2001; 46: 2154-61.

18. Abe R, Shimosegawa $T$, Kimura $K$, Abe $T$, Kashimura J, Koizumi $\mathrm{M}$, et al. The role of endogenous glucocorticoids in rat experimental models of acute pancreatitis. Gastroenterology 1995; 109: 933-43.

19. Osman MO, Jacobsen NO, Kristensen JU, Larsen CG, Jensen $\mathrm{SL}$. Beneficial effects of hydrocortisone in a model of experimental acute pancreatitis. Dig Surg 1999; 16: 214-21.

20. Sun W, Watanabe $Y$, Toki A, Wang ZQ. Beneficial effects of hydrocortisone in induced acute pancreatitis of rats. Chin Med J (Engl) 2007; 120: 1757-61.

21. Kuraishi $Y$, Uehara $T$, Watanabe $T$, Ashihara N, Ozawa M, Kanai $\mathrm{K}$, et al. Corticosteroids prevent the progression of autoimmune pancreatitis to chronic pancreatitis. Pancreatology 2020; 20: 1062-8.

22. Matsubayashi $H$, Ishiwatari $H$, Imai $K$, Kishida $Y$, Ito $S$, Hotta $\mathrm{K}$, et al. Steroid Therapy and Steroid Response in Autoimmune Pancreatitis. Int J Mol Sci 2019; 21: 257.

23. Takaoka K, Kataoka K, Sakagami J. The effect of steroid pulse therapy on the development of acute pancreatitis induced by closed duodenal loop in rats. J Gastroenterol 2002; 37: 537-42. 